\title{
Erratum
}

\section{Thermoelectric Characteristics in MBE-Grown HgCdTe-Based Superlattices}

\author{
S. VELICU, ${ }^{1,4}$ C.H. GREIN,${ }^{1}$ J. ZHAO,${ }^{1}$ Y. $\mathrm{CHANG},{ }^{2}$ S.-Y. AN, ${ }^{2}$ A. YADAV, ${ }^{3}$ \\ and K.P. PIPE ${ }^{3}$ \\ 1.-EPIR Technologies, Inc., 590 Territorial Dr., Unit B, Bolingbrook, IL 60440, USA. \\ 2.-Microphysics Laboratory, University of Illinois at Chicago, Chicago, IL 60607, USA. \\ 3.-Mechanical Engineering Department, University of Michigan, Ann Arbor, MI 48109-2125, \\ USA. 4.—e-mail: svelicu@epir.com
}

\section{Erratum to Journal of ELECTRONIC MATERIALS DOI 10.1007/s11664-008-0415-6}

In the above mentioned article, the author "W. Clark" should not have appeared in the authorship list. 